\title{
REPLY TO:
}

\section{"THE NEW CLASSICAL COUNTER-REVOLUTION: FALSE PATH OR ILLUMINATING COMPLEMENT?"}

\author{
Laurence S. Seidman \\ University of Delaware
}

This well written critique of my paper articulates the conciliatory view that new classical economics has been an illuminating complement to Keynesian macroeconomics. This conciliatory view would certainly not satisfy the architects of the new classical counter-revolution who intended to overthrow, not complement, Keynesian macroeconomics. And despite the useful information and arguments presented in this interesting critique, I remain convinced that the new classical economics has been a false path for macroeconomics, not an illuminating complement. Let me explain why.

In the section of the critique, "Oil and the Stagflation of the 1970s," the author correctly recognizes and notes that Gordon, Blinder, Solow, Tobin, Klein and other Keynesians adopted the AD-AS framework during the mid-1970s to integrate supply shocks into the Keynesian framework and explain the partly OPEC-driven mid-1970s stagflation. By the early 1970s Keynesians recognized that the economy has a NAIRU (see the Brookings Papers on Economic Activity issues of the early 1970s) so that a monetary/fiscal expansion that pushed the unemployment rate below this NAIRU would generate rising inflation; Keynesians recognized that the inflation of the 1960s, and some of the inflation of the 1970s, was due to running the unemployment rate below the NAIRU. So by the mid-1970s, Keynesians had a complete explanation for the stagflation of the 1970 s based on both $\mathrm{AD}$ and AS.

What new contribution did the new classical model make to explaining the stagflation of the 1970s? None. In 1973, 1974, and 1975, the unemployment rate rose from $4.9 \%$ to $5.6 \%$ to $8.5 \%$ and the inflation rate rose from $5.6 \%$ to $9.0 \%$ to $9.4 \%$ ? So how were these data generated by a new classical economy with instantaneous labormarket clearing and rational expectations? Incredibly, Lucas and Sargent never even tried to answer this simple question. Instead, they spent their entire paper attacking Keynesian models of the 1960s. But by the mid-1970s, Keynesian models explained the stagflation partly by excess demand pushing the unemployment rate below the NAIRU (prior to 1974) and partly by the oil supply shock from OPEC. In a later interview Lucas excused his exclusive focus on Keynesian models of 1968 by saying he couldn't be expected to respond to a Keynesian model of 1988. But what about a Keynesian model of 1978, the year of the conference? Who got it right in 1978: Keynesians like Gordon, or new classicals like Lucas and Sargent?

Laurence S. Seidman: Department of Economics, University of Delaware, Purnell Hall, University of Delaware, Newark, DE 19716. E-mail: seidmanl@lerner.udel.edu. 
In the second section of the critique, "New Classical Influences on Macroeconomic Policymaking," the author credits new classical economists with their emphasis on expectations. But new classical economists did not discover the importance of expectations. Keynes emphasized the crucial role that entrepreneurs' expectations play in driving business investment in plant and equipment, and hence, aggregate demand in the economy; and the importance of expectations of inflation dominated Brookings Institution conferences in the early 1970s (check early 1970s issues of the Brookings Papers on Economic Activity edited by Keynesians Okun and Perry).

Fed chairmen Martin (in the 1960s) and Burns (in the 1970s) both tried hard to shape expectations by publicly and repeatedly emphasizing that they would keep inflation low. Burns twice helped generate a recession (1969-70 and 1974-75) by tightening money and raising interest rates in order to fight inflation. In both episodes Burns succeeded in temporarily knocking down inflation. The only period when the Fed chairman was soft on inflation was 1972 when Burns provided stimulus to help Nixon's re-election, and Miller's few months (1978-79) as chairman during the Carter years. Faced with another surge in oil prices in the late 1970s, it took Volcker over two years before he succeeded in turning the tide against inflation-this time, in contrast to Burns, with the help of declining world oil prices. Unfortunately we will never know how Volcker and Greenspan would have done if they had been chairmen in the 1970s, or how Burns would have done if he faced falling rather than rising oil prices. But it is re-writing history to claim that Martin and Burns (except for 1972) were softer on inflation than Volcker and Greenspan.

One way to see how little new classicals have affected policy-making is to imagine the alarm that would have swept through financial markets had Lucas or Sargent or Prescott, rather than Bernanke, been nominated to replace Greenspan. Bernanke met with widespread approval because he uses the same Keynesian framework as Greenspan and is committed to using counter-cyclical monetary policy to combat inflation when demand is excessive and combat recession when demand is deficient. Bernanke may have learned other things from Lucas, but not how to conduct countercyclical monetary policy.

In the section of the critique, "Real Business Cycle Theory," the author downplays its complete failure to explain the Great Depression. Keynesian economists have long conceded that after 1933 FDR's NIRA regulations may have inhibited recovery from the Depression. But for three long years from 1930 to the end of 1932, before FDR became president, output collapsed and the unemployment rate rose from about $5 \%$ to an unprecedented (before or since) 20\%. What does real business cycle theory (and its architect Prescott) have to say about that? Nothing. No, worse than that, it says that labor is always on its supply curve (the labor market clears instantaneously) so this rise in the unemployment rate was "voluntary" and "optimal." Incredible.

As for normal times, economists have always recognized that the pace of technological change varies over time, and affects output growth in the short-run as well as the long-run. What is distinct about real business cycle theory is its assertion that output is governed by technological shocks, positive and negative (the negative shocks are never specified) hitting an economy in which a competitive labor market always clears instantaneously. 
Finally, in the section of the critique, "New Classical Economics in the Textbooks," the author credits new classicals with reducing the use of the phrase "involuntary unemployment" in undergraduate textbooks. But the leading textbooks, such as Blanchard, Mankiw, Abel/Bernanke, all write favorably about the use of counter-cyclical monetary policy to combat recession as well as inflation. In discussing recession, these texts do not explicitly discuss involuntary unemployment because it is taken for granted-the whole discussion and analysis takes it as obvious that unemployment generated by recession is involuntary and non-optimal and should therefore be combated by counter-cyclical monetary policy. These texts show how a shift up of the aggregate supply curve can generate some inflation and create a dilemma for the Fed (which to fight_-inflation or recession?) — this "cost push" inflation is usually illustrated by oil prices rather than wages because oil prices were more important in the 1970s, but the framework can handle either one. A genuinely new classical undergraduate textbook would need to contend, in plain English, that counter-cyclical monetary policy should not be used to combat recessions because recessions do not imply involuntary unemployment. Such assumptions can hide nicely behind mathematics in graduate programs, but would meet with disbelief if stated in plain English to undergraduates.

In the conclusion of the critique, the author notes the value of the "interplay of ideas" which helps avoid "complacency." Yes, complacency is harmful and criticism is often productive. But that doesn't mean that any criticism is as good as its target, or that progress is always made by taking as much from one as from the other. Sometimes it is best for the critic to defeat the target; and sometimes it is best for the target to defeat the critic. Which applies to new classical economics? If it turns out that the emperor has no clothes (despite lots of mathematics), then it is best to say it. So I can't join the effort at conciliation. New classical economics is a false path for macroeconomics, not an illuminating complement. 